\title{
LIBROS
}

\section{PROTOCOLO HOTELERO INTERNACIONAL} Angela García, 2015, España, editorial, núm. págs.

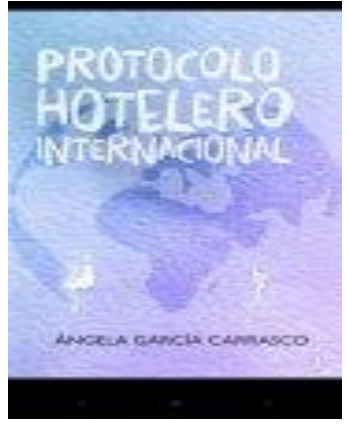

Angela García

Universidad

\section{agcagc1971@hotmail.com}

Recepción: 27/04/2015 Revisión: 01/06/2015 Aceptación:01/07/2015 Publicación 01/07/2015

\section{Enlace web}

Angela Garcia , hotelera de profesión y apasionada del protocolo, plasma en su primer libro la "liason" de estos dos mundos que se necesitan mutuamente y se retro-alimentan, con una visión diferente y única interpreta las necesidades del mundo actual, y con su " Decálogo de Actuación " da las pautas para conseguir mejorar la comunicacion y el respeto entre los profesionales de ambos sectores y todo su publico, para obtener asi el éxito en las relaciones humanas y de negocios . 